\begin{tabular}{|l|l|}
\hline & $\begin{array}{l}\text { JANHUS Journal of Animal Husbandry Science } \\
\text { Jurnal IImu Peternakan } \\
\text { Fakultas Pertanian, Universitas Garut } \\
\text { ISSN : 2548-7914 }\end{array}$ \\
\hline
\end{tabular}

\title{
PENGARUH PENAMBAHAN TEPUNG KUNYIT (Curcuma domestica) DALAM RANSUM TERHADAP PERFORMAN AYAM BROILER
}

\author{
Andri Hendriana, Titin Nurhayatin, Ibrahim Hadist \\ Program Studi Peternakan Fakultas Pertanian, Univerditas Garut \\ Jl. Raya Samarang No.52 A Hampor Garut \\ Email: titinnurhayatin36@yahoo.co.id
}

\begin{abstract}
Abstrak
Penelitian ini bertujuan untuk mengetahui pengaruh penambahan tepung kunyit (Curcuma domestica) dalam ransum terhadap performan ayam broiler, penelitian ini dilaksanakan di kampung Cihuni Desa Cihuni Kecamatan Pangatikan Kabupaten Garut Selama 5 (lima) minggu. Rancangan yang digunakan adalah Rancangan Acak Lengkap (RAL) yang terdiri dari 6 perlakuan dengan masing-masing perlakuan diulang $3 \mathrm{kali}$, adapun perlakuannya sebagai berikut : $\mathrm{R} 1=$ Ransum Tanpa tepung kunyit + air minum tanpa vitachick,. R2 = Ransum tanpa tepung kunyit + Air minum dengan vitachick, R3 $=$ Ransum $+0,2 \%$ Tepung Kunyit, R4 = Ransum $+0,4 \%$ Tepung Kunyit, R5 = Ransum + 0,6 \% Tepung Kunyit, R6 = Ransum + 0,8 \% Tepung Kunyit, dan peubah yang diukur meliputi : konsumsi ransum, pertambahan bobot badan, konversi ransum, konsumsi air minum serta mortalitas, kemudian dilakukan analisis ragam pada data peubah yang diukur dan bila hasil sidik ragam menunjukkan pengaruh perlakuan memberikan perbedaan yang nyata terhadap peubah yang diukur, maka dilanjutkan dengan Uji Jarak Berganda Duncan. Adapun hasil penelitian menunjukkan pengaruh perlakuan memberikan hasil yang berbeda nyata terhadap pertambahan bobot badan $(\mathrm{P}<0.05)$, tetapi tidak memberikan perbedaan yang nyata $(\mathrm{P}>0.05)$ terhadap konsumsi ransum $(\mathrm{g})$, konversi ransum serta mortalitas. Hasil Uji jarak berganda Duncan terhadap pertambahan bobot badan adalah sebagai berikut : Perlakuan R6 dan R5 memberikan pertambahan bobot badan terbesar namun antara R5 dan R6 tidak berbeda nyata, tetapi berbeda nyata $(\mathrm{P}<0.05)$ terhadap perlakuan $\mathrm{R} 1$ sampai $\mathrm{R} 4$, namun antara Perlakuan R1 sampai R4 tidak berbeda nyata.
\end{abstract}

Kata kunci: kunyit, ransum, performa, broiler

\section{Pendahuluan}

Ayam broiler memiliki potensi yang besar dalam memberikan sumbangan terhadap pemenuhan kebutuhan konsumsi protein hewani. Kelemahan ayam broiler yaitu mudah mengalami stres akibat panas dan mudah terserang penyakit akibat virus, bakteri, kapang dan lain-lain. Kondisi tersebut menyebabkan terhambatnya pertumbuhan, penurunan produksi dan kualitas ayam broiler. peternak mengatasi permasalahan tersebut dengan memberikan obatobatan sintetik seperti antibiotik. 
Antibiotik baik secara mandiri maupun dalam bentuk gabungan dengan multi vitamin dan mineral sebagai imbuhan pakan biasa ditambahkan pada ransum atau air minum ternak unggas yang mempunyai daya kerja sebagai pengontrol bibit penyakit yang mengganggu metabolisme ternak, merangsang pertumbuhan organisme yang dapat mensintesis vitaminvitamin dan meningkatkan kapasitas serap saluran pencernaan Sihombing, 1997). Penggunaan antibiotik yang tidak mematuhi aturan pemakaian dapat menimbulkan resistensi mikroba dan residu pada produk ternak, sehingga mengganggu kesehatan manusia. Resistensi mikroba dapat ditransfer dari ternak ke tubuh manusia, melalui kontak langsung manusia dengan ternak maupun secara tidak langsung melalui konsumsi produk hewani. (Soeharsono, 1992). Penggunaan herbal merupakan salah satu solusi sebagai pengganti antibiotik agar tetap menghasilkan produktivitas ayam broiler yang optimal

Salah satu herbal yang cukup potensial untuk dimanfaatkan sebagai antibiotik alami adalah kunyit (Curcuma domestica). kunyit merupakan salah satu bahan fitofarmaka potensial yang dapat digunakan sebagai imbuhan pakan pengganti antibiotika untuk unggas, karena kunyit mengandung zat aktif kurkumin yang dapat berfungsi sebagai antimikroba, dan dalam dosis yang tepat dapat merelaksasi usus sehingga diharapkan berpengaruh positif terhadap pertumbuhan.

Penggunaan kunyit sebagai imbuhan pakan bisa dilakukan dengan cara mencampurkan langsung ke dalam ransum atau melalui air minum, namun pencampuran kunyit ke dalam ransum efektif dibandingkan dengan melalui air minum dari segi kemudahan pelaksanaannya karena jika dicampurkan ke dalam air minum harus selalu diaduk untuk menghindari pengendapan kunyit di bagian bawah tempat minum. Penggunaan kunyit pun bisa diberikan dalam bentuk segar maupun dalam bentuk tepung yang dikeringkan hal ini mengakibatkan dosis yang digunakan jadi berbeda, itulah yang membuat mengapa pada penelitian-penelitian pemanfaatan kunyit terdahulu memperlihatkan penggunaan dosis kunyit yang sangat berbeda besarannya antar penelitian. Penggunaan kunyit dalam bentuk tepung kering lebih awet, serta lebih terjamin kekonsistenan kandungan aktifnya dalam jangka waktu lama dibandingkan dengan kunyit segar yang semakin lama disimpan akan rusak. Berdasarkan alasan di atas maka penulis dalam penelitian menggunakan tepung kunyit yang dicampurkan ke dalam ransum.

Penggunaan kunyit sebagai imbuhan pakan diharapkan dapat menggantikan fungsi antibiotika dalam imbuhan pakan (feed aditif yang sangat umum digunakan peternak dan mudah didapat) untuk meningkatkan produktivitas ternak unggas dan efisiensi penggunaan pakan. Pengurangan penggunaan antibiotika ini akan memberikan sumbangan peningkatan kualitas produk peternakan dan kesehatan konsumen. Oleh karena itu, dilakukan penelitian untuk menguji efektivitas kunyit sebagai imbuhan pakan pengganti antibiotika dalam ransum ayam broiler.

Salah satu usaha untuk memacu pertumbuhan serta meningkatkan efisiensi pakan ayam broiler yang dilakukan oleh perusahaan pakan ternak merekomendasikan untuk menggunakan imbuhan pakan berupa multivitamin mengandung antibiotic. Penggunaan imbuhan pakan menandung antibiotik perlu dicermati secara bijak mengingat dampak pengunaan antibiotik dalam dosis kecil yang terus menerus, disinyalir kurang menguntungkan terhadap kesehatan konsumen, akibat dari residu yang tertinggal pada karkas ternak dan atau menyebabkan resistensi mikroba.

Kunyit yang dicampurkan baik dalam ransum maupun minuman pada ayam broiler disinyalir dapat menghilangkan bau kotoran dan menambah berat badan ayam (Winarno, 2003). Menurut Samarasinge dkk., (2003), penambahan kunyit dalam ransum ayam broiler dapat memperbaiki pertumbuhan dan efisiensi pakan serta bisa digunakan sebagai alternatif pengunaan antibiotik. 
Hasil penelitian Sauland Sinaga (2009) menghasilkan bahwa penggunaan tepung kunyit mulai $0,2 \%-0,6 \%$ efektif dalam menggantikan antibiotic virginiamycin sehingga dihasilkan konversi, pertambahan bobot badan serta ketebalan lemak abdominal yang tidak berbeda nyata dengan babi yang diberi antibiotic, namun secara numeric pada $0,6 \%$ terdapat penurunan efisiensi ransum dan pertambahan bobot badan terbaik pada penggunaan kunyit $0.4 \%$. Hasil yang senada diperoleh dari penelitian Sinurat, dkk (2009) menggunakan tepung kunyit pada 900 ekor DOC broiler dengan dosis setara $0.2 \%-0,6 \%$ dalam ransum sebagai pengganti antibiotic bacitracin memberikan hasil yang tidak berbeda nyata terhadap semua parameter pertumbuhan, lemak abdominal, daya cerna serta kolesterol darah, hal ini mengindikasikan bahwa kunyit dalam ransum efektif menggantikan antibiotic dalam ransum.

Jadi berdasarkan hal tersebut maka tujuan penelitian adalah mengetahui pengaruh pemberian tepung kunyit dalam ransum terhadap pertumbuhan ayam broiler dan mengetahui dosis optimal penambahan tepung kunyit dalam ransum terhadap pertumbuhan ayam broiler.

\section{$2 \quad$ Metodologi}

\subsection{Waktu dan Tempat}

Penelitian ini dilaksanakan di kampung Cihuni Desa Cihuni Kecamatan Pangatikan Kabupaten Garut Selama 5 (lima) minggu.

\subsection{Bahan dan Metoda Penelitian}

\section{Bahan Percobaan}

Ternak yang digunakan adalah 90 ekor ayam broiler berumur 1 hari (DOC) CP 707 strain avian, dipelihara dari umur 1- 5 minggu tanpa pemisahan jenis kelamin. ayam tersebut di bagi secara acak menjadi 18 unit kandang sehingga masing-masing kandang berisi 5 ekor ayam .

\section{Kandang dan Perlengkapan}

Kandang yang digunakan adalah kandang alas liter yang dibuat dari bambu dengan ukuran, 1 x 0.62.5 m, Terdiri dari 18 buah kandang dengan dimensi tiap kandang, Panjang 100 $\mathrm{cm}$, lebar $62.5 \mathrm{~cm}$, tinggi $75 \mathrm{~cm}$ tiap kandang berisi 5 ekor ayam. Masing-masing kandang diberi nomor perlakuan serta nomor ulangan dan dilengkapi dengan tempat ransum dan air minum, lampu pijar 40 watt diletakkan beberapa $\mathrm{cm}$ dari punggung DOC, dan dinaikkan sedikit demi sedikit sesuai umur ayam sampai umur 2 minggu sebagai pemanas buatan serta 1 buah lampu sebagai penerang kandang.

\section{Peralatan yang Digunakan}

Peralatan yang digunakan pada penelitian yaitu:

- Timbangan gantung dengan kapasitas $10 \mathrm{~kg}$ untuk menimbang ransum.

- Timbangan "O Hause" kapasitas 310 dan 2610 gram untuk menimbang ransum perlakuan, sisa ransum, ayam broiler.

- Thermometer digunakan untuk mengukur tempertur kandang.

- Tempat ransum dan air minum.

- Alat penghancur, pisau, dan plastik untuk ransum

\section{Pembuatan Tepung Kunyit.}

Kunyit diiris tipis-tipis dan dilayukan di dalam ruangan selama 48 jam, dijemur sampai kering kadar air sekitar $12 \%$ kemudian digiling sampai menjadi tepung. Selanjutnya, tepung kunyit dicampurkan dengan ransum dalam persentase tertentu sesuai perlakuan penelitian. 


\section{Ransum dan Perlakuan Penelitian}

Ransum yang digunakan selama penelitian menggunakan ransum periode Starter, dengan kandungan nutrisi sesuai SNI Pakan Ayam Broiler Starter 1995, sebagai berikut :

Tabel 1. Kandungan Nutrisi Ransum Penelitian Ayam Broiler (BR 1)

\begin{tabular}{lc}
\hline \multicolumn{1}{c}{ Kandungan Nutrisi Ransum Starter } & Persentase (\%) \\
\hline Kadar Air (maksimum) & $14,0 \%$ \\
Protein Kasar & $18,0-23,0 \%$ \\
Lemak Kasar & $2,5-7,0 \%$ \\
Serat Kasar (maksimum) & $7,0 \%$ \\
Abu & $5,0-8,0 \%$ \\
Calcium (Ca) & $0,9-1,2 \%$ \\
Phosphor (P) & $0,7-1,0 \%$ \\
L-Lysine (maksimum) & $1,10 \%$ \\
DL-Methionine (maksimum) & $0,50 \%$ \\
Energi Metabolis kkal/kg & 3000 \\
\hline
\end{tabular}

Sumber : SNI Pakan Broiler Starter 1995

\section{Perlakuan Penelitian:}

1. $R 1=$ Ransum tepung kunyit + air minum tanpa multivitamin mengandung antibiotik

2. $\mathrm{R} 2=$ Ransum tanpa tepung kunyit + Air minum multivitamin mengandung antibiotik

3. $\mathrm{R} 3=$ Ransum mengandung tepung kunyit $0,2 \%$

4. $\mathrm{R} 4=$ Ransum mengandung tepung kunyit $0,4 \%$

5. $\mathrm{R} 5=$ Ransum mengandung tepung kunyit $0,6 \%$

6. R6 - Ransum mengandung tepung kunyit $0,8 \%$

\section{Tahap pengumpulan Data}

Pengumpulan data bobot badan di lakukan pada saat DOC tiba dan setiap akhir minggu pertama sampai akhir minggu kelima. Sisa konsumsi ransum di catat setiap akhir minggu pertama sampai akhir minggu kelima.Temperatur dan kelembaban relatif kandang dicatat setiap hari.

7. Peubah yang diamati

1) Konsumsi Ransum

2) Pertambahan Bobot Badan

3) Konversi ransum

\section{Rancangan Percobaan}

Penelitian dilakukan secara eksperimen mengunakan Rancangan Acak Lengkap (RAL), dengan 6 perlakuan dan masing-masing perlakuan diulang sebanyak 3 kali sehingga terdapat 18 unit percobaan, masing-masing perlakuan terdiri dari 5 ekor doc broiler.

Data yang diperoleh diolah dan dianalisis mengunakan Analisis ragam (Uji F). dan bila terdapat perbedaan maka dilakukan analisis lanjut Uji Jarak Berganda Duncan.

\section{Hasil dan Pembahasan}

\section{Pengaruh perlakuan Terhadap Konsumsi Ransum}


Vol. 2; No. 2; Juni 2018

Halaman 15-21

Tabel 2. Rataan pengaruh perlakuan terhadap konsumsi ransum total/ekor

\begin{tabular}{llllllll}
\hline \multicolumn{7}{c}{ Perlakuan } \\
\hline Ulangan & R1 & R2 & R3 & R4 & R5 & R6 & Total \\
\hline 1. & 3200,0 & 3166,4 & 3200,0 & 3177,9 & 3171,1 & 3175,8 & \\
2. & 3194,0 & 3198,4 & 3172,4 & 3177,8 & 3173,0 & 3200,0 & \\
3. & 3200,0 & 3162,2 & 3188,5 & 3178,2 & 3179,4 & 3200,0 & \\
\hline Total & 9594,0 & 9527,0 & 9560,9 & 9523,9 & 9523,5 & 9575,8 & 57315,1 \\
Rataan & 3198,0 & 3175,7 & 3187,0 & 3187,0 & 3174,5 & 3191,9 & \\
\hline
\end{tabular}

Guna melihat pengaruh perlakuan terhadap konsumsi ransum maka dilakukan analisis ragam, berdasarkan hasil sidik ragam ternyata pengaruh penggunaan tepung kunyit terhadap konsumsi ransum menunjukkan tidak berbeda nyata $(\mathrm{P}>0.05)$.

Ayam mengkonsumsi ransum untuk memenuhi kebutuhan energinya, energi metabolisme ransum yang digunakan dalam penelitian ini sama sehinga konsumsi ransumpun tidak berbeda. Sejalan dengan pendapat tersebut Sturkie,1986, mengemukakan bahwa konsumsi ransum dipengaruhi tempertur lingkungan, panjang siang, aktifitas, rasa dari ransum, serta ketersediaan air. karena kondisi penelitian dan jenis ayam yang dipeliharanya sama, maka konsumsi ransumpun tidak berbeda.

\section{Pengaruh Perlakuan terhadap Pertambahan Bobot Badan}

Guna mengetahui pengaruh perlakuan terhadap pertambahan bobot badan dilakukan analisis ragam yang hasilnya menunjukkan bahwa pengaruh penggunaan tepung kunyit memberikan perbedaan yang nyata $(\mathrm{P}<0.05)$ terhadap pertambahan bobot badan, dan untuk mengetahui perlakuan mana yang memberikan perbedaan maka dilakukanan Uji Jarak Berganda Duncan, yang bisa dilihat di bawah ini :

Tabel 3. Uji Jarak Berganda Duncan Pengaruh Perlakuan terhadap Pertambahan Bobot Badan

\begin{tabular}{|c|c|c|c|c|c|}
\hline $\begin{array}{l}\text { Urutan } \\
\text { Perlakuan }\end{array}$ & Rataan & Beda 2 Rata-Rata & $\begin{array}{l}\text { SSR } \\
0,05 \\
\end{array}$ & $\begin{array}{l}\text { LSR } \\
0,05 \\
\end{array}$ & Signifikansi \\
\hline R6 $(0.4 \%)$ & 2330,4 & & & & $\mathrm{a}$ \\
\hline $\mathrm{R} 5(0,3 \%)$ & 2250,5 & 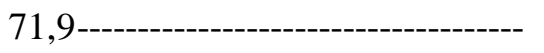 & , 08 & 76,3 & a \\
\hline $\mathrm{R} 4(0,2 \%)$ & 2158,5 & $171,9100,0$ - 10 & 3,23 & 80,1 & $\mathrm{~b}$ \\
\hline R3 $(0,1 \%)$ & 2025,2 & 305,2 233,3 133,3 ---------------- & 3,31 & 82,1 & $\mathrm{c}$ \\
\hline $\mathrm{R} 2$ (FA) & 1919,5 & $410,9 \quad 339,0 \quad 239,0 \quad 106,2-------$ & 3,37 & 83,6 & $\mathrm{~d}$ \\
\hline R1(control) & 1816,7 & $\begin{array}{lllll}513,7 & 441,8 & 341,8 & 208,5 & 102,8\end{array}$ & 3,41 & 84,7 & $\mathrm{e}$ \\
\hline
\end{tabular}

Keterangan : Signifikansi hurup yang tidak sama kearah kolom menunjukan pengaruh berbeda nyata $(\mathrm{P}<0.05)$

Berdasarkan tabel di atas, dapat dilihat bahwa penggunaan tepung kunyit dalam ransum R5 $0.3 \%$ dan R6 0.4\% memberikan pertambahan bobot badan tertinggi tapi tidak berbedanyata diantara keduanya, hal ini kemungkinanan disebabkan karena manfaat dari kunyit sudah maksimal dengan penggunaan $0,3 \%$ dan $0,4 \%$ namun berbedanya $(\mathrm{P}<0.05)$ dibandingkan dengan R0-R4.

Kunyit mengandung enzim amylase, lipase dan protease yang berguna untuk meningkatkan pencernaan bahan pakan seperti karbohidrat, lemak, dan protein. Minyak atsiri yang dikandung kunyit dapat mempercepat pengosongan isi lambung (Arnold Sinurat, 2009). Dengan demikian berpengaruh baik dalam meningkatkan pertambahan bobot badan ayam dengan 
perlakuan R1 - R4, begitu pula pertambahan bobot badan ayam broiler antara R1 sampai R4 secara berturutan memberikan perbedaan yang nyata memberikan pertambahan bobot badan semakin kecil.

Kunyit mampu membantu meningkatkan daya tahan tubuh karena kandungan utama kunyit adalah kurkumin dan minyak atsiri berfungsi untuk pengobatan anti inflamasi, anti oksidan, anti mikroba serta dapat meningkatkan kerja organ pencernaan unggas dengan merangsang dinding kantong empedu mengeluarkan cairan empedu dan merangsang keluarnya getah pankreas yang mengandung enzim pecerna..

\section{Pengaruh Perlakuan terhadap Konversi Ransum}

Untuk melihat pengaruh perlakuan terhadap konversi ransum maka dilakukan analisis ragam berdasarkan analisis ragam menunjukkan hasil bahwa pengaruh penggunaan tepung kunyit dalam ransum tidak memberikan perbedaan yang nyata $(\mathrm{P}>0.05)$ tehadap konversi ransum ayam broiler.

Tabel 4 : Rataan Konversi Ransum Total Ayam Broiler /ekor selama 5 minggu penelitian

\begin{tabular}{lccccccc}
\hline & \multicolumn{7}{c}{ Perlakuan } \\
\hline Ulangan & $\mathrm{R} 1$ & $\mathrm{R} 2$ & $\mathrm{R} 3$ & $\mathrm{R} 4$ & $\mathrm{R} 5$ & $\mathrm{R} 6$ & Total \\
1 & 1,73 & 1,64 & 1,57 & 1,53 & 1,41 & 1,40 & \\
2 & 1,79 & 1,66 & 1,57 & 1,47 & 1,42 & 1,36 & \\
3 & 1,76 & 1,66 & 1,57 & 1,42 & 1,39 & 1,35 & \\
\hline Total & 5,28 & 4,96 & 4,71 & 4,42 & 4,22 & 4,10 & 27,69 \\
Rataan & 1,76 & 1,65 & 1,57 & 1,47 & 1,41 & 1,37 & \\
\hline
\end{tabular}

Untuk melihat pengaruh perlakuan terhadap konversi ransum maka dilakukan analisis ragam berdasarkan analisis ragam menunjukkan hasil bahwa pengaruh penggunaan tepung kunyit dalam ransum tidak memberikan perbedaan yang nyata $(\mathrm{P}>0.05)$ tehadap konversi ransum ayam broiler.

\section{$4 \quad$ Kesimpulan dan Saran}

Penggunaan tepung kunyit dalam ransum tidak berpengaruh nyata terhadap konsumsi ransum dan konversi ransum, namun berpengaruh nyata terhadap pertambahan bobot badan ayam broiler, yaitu penggunaan tepung kunyit R5 0,3\% dan R6 0,4\% memberikan hasil tertinggi terhadap pertambahan bobot badan, dan berbedanyata lebih tinggi dari perlakuan R0 sampai R4, namun diantara ke 4 perlakuan tersebut memberikan pengaruh yang berbedanyata semakin rendah pertambahan bobot badannya seiring dengan menurunnya persentase penggunaan kunyit. Disarankan menggunakan tepung kunyit $0,3 \%$ dalam ransum untuk mendapatkan pertambahan bobot badan terbaik.

\section{$5 \quad$ Daftar Pustaka}

Arnold Sinurat, T. Purwadaria, I.A.K.Bintang, P.P Ketaren, N.Bermawi, M.Raharjo. 2009. Pemanfatan Kunyit dan Temulawak sebagai Imbuhan Pakan untuk Ayam Broiler. Balai Penelelitian Ternak dan Balitro Aromatik. Bogor 
Bintang, I.A.K. dan A.G. Nataamijaya. 2005. Pengaruh penambahan tepung kunyit terhadap performans broiler. Pros, Seminar Nasional Teknologi Peternakan dan Veteriner. Bogor, 12-13 September 2005. Puslitbang Peternakan. Bogor. hlm.773-777.

Sauland Dinaga. 2009. Pengaruh Pemberian Tepung Kunyit Sebagai Pengganti Antibiotik Sintetis dalam Ransum Babi Kastrasi Periode Grower. Thesis. Institut Pertanian Bogor. Bogar

Samarasinghe, K., C. Wenk, K. F. S. T. Silva, and J. M. D. M. Gunaseker. 2003. Tumeric (Curcuma longa) root powder and Mannanoligosaccarides as alternatives to antibiotics in broiler chicken diets. Asian-Australian J. Anim. Sci. 16(10) : 1495-1500

Soeharsono. 1976. Respon Broiler terhadap Berbagai Kondisi Lingkungan. Disertarsi Universitas Padjadjaran. Bandung.

Soeharsono, 1997. Probiotik, Sebagai Alternatif penganti Antibiotik dalam Bidang peternakan. Fapet. Unpad, Bandung.

Standar Nasional Indonesia Pakan Ayam Broiler Starter. 1995. 